\title{
TOLERANSI DAN PENGATURAN OSMOTIK NILA GIFT (Genetic Improvement of Farmed Tilapias) YANG DIPAPAR DENGAN TINGKAT SALINITAS BERBEDA
}

\author{
Aan Fibro Widodo dan Markus Mangampa \\ Balai Riset Perikanan Budidaya Air Payau \\ Jl. Makmur Dg. Sitakka No. 129, Maros 90512, Sulawesi Selatan \\ E-mail:nbiolk@gmail.com
}

(Naskah diterima: 20 Juli 2011; Disetujui publikasi: 29 September 2011)

\begin{abstract}
ABSTRAK
Penelitian ini dilakukan untuk mempelajari toleransi dan pengaturan osmotik ikan nila GIFT terhadap paparan salinitas yang berbeda. Penelitian dilaksanakan di Laboratorium Basah Instalasi Riset Maranak, Balai Riset Perikanan Budidaya Air Payau (BRPBAP), Maros.

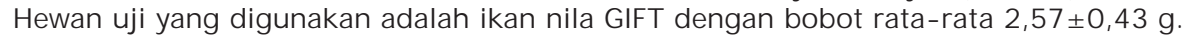
Penelitian dirancang dengan pola rancangan acak lengkap (RAL) yang terdiri atas 4 perlakuan dan 3 ulangan. Perlakuan yang diujikan adalah pemaparan ikan pada medium bersalinitas $5 \pm 2 \mathrm{ppt}, 15 \pm 2 \mathrm{ppt}, 25 \pm 2 \mathrm{ppt}$, dan $35 \pm 2 \mathrm{ppt}$. Peubah yang diamati adalah tingkat kerja osmotik, kapasitas osmoregulasi, dan kadar air badan. Hasil penelitian menunjukkan bahwa fluktuasi salinitas medium berpengaruh terhadap regulasi osmotik namun tidak berpengaruh terhadap persentase kadar air badan. Regulasi osmotik nila GIFT optimal didapatkan pada kisaran salinitas $15 \pm 2$ ppt sampai salinitas $25 \pm 2$ ppt. Pada kisaran salinitas ini, nila GIFT mampu melakukan pengaturan osmoregulasi internal menuju pemulihan (keseimbangan osmotik) mendekati tingkat osmotik lingkungan habitat aslinya setelah 24 jam cekaman salinitas. Hal ini mengindikasikan bahwa nila GIFT lebih toleran terhadap kisaran nilai salinitas air yang tinggi dibandingkan dengan nila varietas lokal lainnya.
\end{abstract}

KATA KUNCI: osmolalitas, nila GIFT, salinitas

ABSTRACT: Tolerance and osmotic regulation of GIFT tilapia (Genetic Improvement of Farmed Tilapias) exposed to different salinity levels. By: Aan Fibro Widodo and Markus Mangampa

The aim of this study was to determine the tolerance and osmotic regulation of GIFT tilapia exposed to different salinity levels. The research was conducted at the Wet Laboratory of Maranak Research Installation belonged to the Research Institute For Coastal Aquaculture (RICA). GIFT tilapia juveniles were used in the experiment with initial weight average of $2.57 \pm 0.43 \mathrm{~g}$. The study employed completely randomized design (CRD) consisted of four treatments and three replications. The treatments were subjecting the fish to different salinity levels of $5 \pm 2$ ppt salinity, $15 \pm 2$ ppt, 25 \pm 2 ppt, and $35 \pm 2$ ppt. Measured variables were level of osmotic activity, capacity of osmoregulation, and water content in fish body mass. The results showed that the treatments affected the osmotic regulation process in the fish but had no effect on the percentage of body water content. Among the treatments, the optimum osmotic regulation was achieved by GIFT tilapia exposed to salinity treatment of $15 \pm 2$ ppt to 
$25 \pm 2$ ppt salinity. At this salinity range, iGIFT tilapia was able to regulate its internal osmoregulation (osmotic balance) to recover close to the level of osmotic pressure in its natural habitat after 24 hours of salinity stress. The results showed that the GIFT tilapia is more tolerant to higher salinity ranges compared to other local varieties of tilapia.

\section{KEYWORDS: osmolality, GIFT tilapia, salinity}

\section{PENDAHULUAN}

Nila GIFT merupakan varietas unggul yang berhasil dikembangkan oleh International Centre for Living Aquatic Resources Management (ICLARM) dengan pembiayaan oleh Asian Development Bank (ADB) dan United Nation Development Programme (UNDP). Nila GIFT merupakan hasil program kawin silang dan seleksi famili dari jenis- jenis nila lokal yang berasal dari beberapa negara seperti Taiwan, Mesir, Thailand, Ghana, Singapura, Israel, Senegal, dan Kenya. Nama GIFT dari ikan nila GIFT berasal dari singkatan Genetic Improvement of Farmed Tilapias. Varietas unggul ini masuk ke Indonesia pada tahun 1984 dan 1996 dari ICLARM Philipina melalui Balai Riset Perikanan Air Tawar (Hayuningtyas et al., 2009; Bastiawan \& Wahid, 2011).

Secara genetik ikan nila GIFT mempunyai karakteristik genetik yang lebih unggul dibandingkan dengan ikan nila lokal terutama tingkat pertumbuhan yang lebih cepat dan fekunditas (tingkat kesuburan untuk menghasilkan sejumlah telur) lebih tinggi. Dalam waktu 5- 6 bulan ikan nila GIFT mampu mencapai bobot badan sekitar $600 \mathrm{~g}$. Daya tahan badan yang lebih baik memungkinkan nila GIFT lebih toleran terhadap kisaran nilai salinitas air yang tinggi dan lebih tahan terhadap serangan penyakit.

Kemampuan adaptasi yang baik terhadap lingkungan (euryhaline) dan didukung dengan sistem budidaya intensif menyebabkan komoditas ini semakin populer beberapa tahun belakangan ini. Hal ini disebabkan jumlah permintaan yang terus meningkat dari negaranegara seperti Amerika Serikat, Eropa, Jepang, Singapura, dan Hong Kong. Indonesia sejauh ini dikenal sebagai salah satu negara pengekspor ikan nila GIFT terbesar (710 juta ton/ tahun) di samping Taiwan, Costa Rica, Philipina, dan Thailand (FAO, 2004). Peningkatan jumlah permintaan dan ketersediaan lahan perairan payau di Indonesia membuka peluang budidaya ikan nila di perairan payau.
Beberapa penelitian tentang keragaan nila pada media bersalinitas berbeda telah banyak dilaporkan antara lain oleh Watanabe et al. (1985), Villegas (1990), Basiao et al. (2005), Kamal \& Mair (2005), Chowdhury (2006), dan Fineman (2008).

Haryadi (2003) melaporkan bahwa pada ikan nila merah, peningkatan salinitas medium meningkatkan konsentrasi osmotik plasma. Hal senada juga dilaporkan pada kijing air tawar, Velusunio ambiguus Phillipi (Widarto \& Lucas, 1995); ikan mujair, Oreochromis mossambicus (Nolan et al., 1999); sidat, Anguilla bicolor (Susilo \& Sukmaningrum, 2007); dan ikan nila, Oreochromis sp. (Susilo \& Rachmawati, 2008). Gradien osmotik antara cairan badan dengan lingkungan menyebabkan keluar atau masuknya air dengan osmosis secara terusmenerus ke dalam badan dan hilangnya garamgaram badan beserta zat terlarut lainnya melalui urin hipotonisnya (Widarto \& Lucas, 1995). Jika osmosis berlangsung terusmenerus sel akan membengkak dan melisis. Untuk mencegah hal tersebut, organisme perairan melakukan mekanisme pengaturan fisiologisnya untuk mencegah pengaruh dehidrasi dengan menjaga komposisi cairan badan dan osmolalitas yang dikenal dengan proses osmoregulasi. Kenaikan tekanan osmotik hemolimp menunjukkan konsentrasi ion bertambah dengan meningkatnya salinitas eksternal dalam sitoplasma (Pierce, 1982).

Meskipun telah diketahui bahwa nila GIFT memiliki kisaran salinitas yang luas, namun implikasi metabolisme dari kondisi tersebut belum banyak diketahui padahal informasi fisiologi yang berhubungan dengan laju osmoregulasi sangat dibutuhkan. Laju osmoregulasi tampaknya cukup tepat untuk mengukur pengeluaran energi nila GIFT dalam kondisi salinitas tinggi karena umumnya dianggap sebagai salah satu indikator terbaik aktivitas fisiologis umum individu, mengintegrasikan khususnya pertukaran energi yang diperlukan untuk regulasi osmotik. Penelitian ini dilakukan untuk mempelajari 
toleransi dan pengaturan osmotik ikan nila GIFT terhadap paparan salinitas yang berbeda.

\section{BAHAN DAN METODE}

Penelitian dilaksanakan di Laboratorium Basah Instalasi Riset Maranak, Balai Riset Perikanan Budidaya Air Payau (BRPBAP), Maros. Penelitian menggunakan wadah berupa bak fiberglass berukuran panjang, lebar, dan tinggi masing- masing $100 \mathrm{~cm} \times 100 \mathrm{~cm} \times 60 \mathrm{~cm}$. Wadah masing- masing diisi air laut sebanyak $40 \mathrm{~L}$ dan diaerasi terus- menerus. Hewan uji yang digunakan adalah ikan nila GIFT dengan bobot rata- rata $2,57 \pm 0,43 \mathrm{~g}$. Hewan uji ditebar dengan kepadatan 100 ekor/bak yang dipelihara selama 60 hari. Sebelum ditebar ke wadah penelitian terlebih dahulu dilakukan penimbangan bobot dengan menggunakan timbangan elektrik berketelitian 0,01 g. Selama penelitian berlangsung ikan diberi pakan komersial (pelet) dengan komposisi proksimat: lemak $(6,53 \%)$, protein $(27,43 \%)$, serat kasar $(1,45 \%)$, dan abu $(7,79 \%$ (Tahe, 2008). Pemberian dilakukan setiap hari sebesar 5\% biomassa dengan frekuensi pemberian 2 kali/ hari yakni pada pukul 07.00 dan 16.00.

Sumber air yang digunakan terdiri atas air laut bersalinitas 35 ppt. Stok air laut diambil dari perairan Teluk Awerange Kabupaten Barru, Sulawesi Selatan. Untuk mendapatkan media perlakuan sesuai dengan salinitas yang diinginkan maka dilakukan teknik pengenceran dengan air tawar yang bersumber dari air sumur. Pengenceran dilakukan dengan berpedoman pada rumus yang digunakan Anggoro (1992) sebagai berikut: S2 = (a $\times$ S1)/ $(n+a)$, di mana S2 adalah tingkat salinitas yang diinginkan (ppt), S1 adalah tingkat salinitas air laut yang akan diencerkan (ppt), a adalah volume air laut yang diencerkan (L), dan $n$ adalah volume air tawar yang perlu ditambahkan (L).

Penelitian dirancang dengan pola rancangan acak lengkap (RAL) yang terdiri atas 4 perlakuan dan 3 ulangan. Perlakuan yang diujikan adalah pemaparan ikan pada medium bersalinitas $5 \pm 2 \mathrm{ppt}, 15 \pm 2 \mathrm{ppt}, 25 \pm 2 \mathrm{ppt}$, dan $35 \pm 2$ ppt. Sebelum digunakan untuk keperluan penelitian, ikan uji diaklimatisasi terlebih dahulu pada salinitas $2 \pm 2$ ppt selama seminggu agar dapat menyesuaikan diri pada kondisi laboratorium. Untuk menjaga kualitas air media penelitian, maka sisa- sisa pakan dan kotoran ikan uji disipon setiap hari. Untuk mempertahankan salinitas media, maka dilakukan pengukuran salinitas pada setiap pagi dan sore sehari dengan menggunakan hand refraktometer. Jika terjadi peningkatan salinitas, maka dilakukan penambahan air tawar sampai salinitas media sesuai dengan perlakuan.

Peubah yang diamati adalah tingkat kerja osmotik, kapasitas osmoregulasi, dan kadar air badan. Untuk pengukuran tingkat kerja osmotik dilakukan pengambilan darah ikan setelah ikan dipapar pada media uji selama 1 jam, 4 jam, 8 jam, 16 jam, 24 jam, 48 jam, 7 hari dan setelah 2 bulan pemeliharaan.

Darah diambil dari pembuluh darah kaudal dengan memotong sirip ekor sebanyak 0,05 $\mathrm{mL}$ lalu dimasukkan ke dalam tube 1,5 mL yang sebelumnya telah ditambahkan Trisodium Citrate $\left(\mathrm{Na}_{3} \mathrm{C}_{6} \mathrm{H}_{5} \mathrm{O}_{7}\right) 3,8 \%$ sebagai antikoagulan dengan perbandingan 9:1. Nilai osmolalitas plasma darah dan media diukur menggunakan Fiske Model 210 Micro-Osmometer. Pemisahan plasma dari sel darah menggunakan metode Partidge \& Jenkins (2002). Darah disentifuge dengan kecepatan 5000 rpm selama 3 menit. Plasma darah dan air media pemeliharaan diambil sebanyak $20 \mu \mathrm{L}$ untuk pengukuran osmolalitas. Nilai osmolalitas darah dan media kemudian digunakan untuk menghitung kapasitas osmoregulasi. Kapasitas osmoregulasi merupakan rasio antara nilai osmotik plasma dengan nilai osmotik media (Lignot et al., 2000).

Kadar air badan ikan diukur dengan menggunakan metode Susilo \& Sukmaningrum (2007). Badan ikan dikeringkan dalam oven pada suhu $70^{\circ} \mathrm{C}$ selama 5 hari hingga bobot konstan. Selisih bobot badan sebelum dan setelah pengeringan diestimasi sebagai kadar air badan.

Data yang diperoleh dianalisis dengan menggunakan analisis ragam. Uji jarak ganda Duncan digunakan untuk membandingkan perbedaan antara perlakuan. Data hasil pengukuran dianalisis regresi dan korelasi untuk menentukan pola hubungan antara tingkat salinitas dengan tingkat kerja osmotik. Sebagai alat bantu untuk melaksanakan uji statistik tersebut digunakan paket program SPSS.

\section{HASIL DAN BAHASAN}

Mekanisme osmoregulasi merupakan sejumlah mekanisme pengaturan air dan ion dalam badan yang dilakukan untuk mengatasi 
masalah osmotik dan mengatur perbedaan di antara intra sel dan ekstra sel dan di antara ekstrasel dengan lingkungan secara bersamasama (Evans, 1998). Mekanisme osmoregulasi meliputi volume air, kandungan zat terlarut dan distribusi zat terlarut.

Hasil pengamatan pengaruh salinitas terhadap osmolalitas plasma nila GIFT dengan waktu pemaparan yang berbeda tertera pada Gambar 1.

Gambar 1 memperlihatkan bahwa tingkat salinitas media mempengaruhi tingkat osmolalitas plasma ikan nila. Tingkat osmolalitas terendah sebesar $387 \mathrm{mOsm} / \mathrm{kg}$ didapatkan pada pemaparan salinitas $5 \mathrm{ppt}$; disusul secara berurutan pemaparan 15 ppt sebesar 397 $\mathrm{mOsm} / \mathrm{kg}$; 25 ppt sebesar 401 mOsm/ kg; dan tertinggi pada pemaparan 35 ppt dengan osmolalitas plasma sebesar $425 \mathrm{mOsm} / \mathrm{kg}$.

Berdasarkan analisis ragam, perbedaan salinitas tidak berpengaruh nyata $(P>0,05)$ terhadap osmolalitas plasma antara perlakuan medium salinitas 5, 15, dan 25 ppt tetapi berbeda nyata $(P<0,05)$ dengan perlakuan medium salinitas 35 ppt. Perbedaan tingkat osmolalitas plasma terlacak sejak pemaparan 1 jam hingga 24 jam pemaparan. Pada pemaparan ke- 48 , terjadi kematian total ikan pada medium salinitas 35 ppt. Pemaparan pada medium salinitas 5 ppt menghasilkan peningkatan tingkat osmolalitas plasma dimulai dari pemaparan 4 jam hingga 24 jam, namun terjadi penurunan setelahnya hingga 2 bulan pemeliharaan. Hal ini juga terjadi pada perlakuan medium 15 dan 25 ppt. Dari hasil ini dapat diasumsikan bahwa nila GIFT melakukan pengaturan osmoregulasi internal, menuju pemulihan (keseimbangan osmotik) mendekati tingkat osmotik lingkungan habitat aslinya.

Pengaruh fluktuasi salinitas terhadap osmolalitas plasma terukur dari nilai kapasitas osmoregulasi yang dihasilkan. Kapasitas omoregulasi nila GIFT tertera pada Gambar 2. Berdasarkan analisis ragam, perbedaan salinitas, dan lamanya waktu pemaparan berpengaruh nyata $(P<0,05)$ terhadap osmolalitas plasma nila GIFT. Ikan yang dipapar dengan media bersalinitas $5 \pm 2$ ppt pada semua waktu pemaparan menghasilkan kapasitas osmoregulasi 1,49-1,74. Nilai ini menunjukkan bahwa nilai osmolalitas plasma ikan > osmolalitas medium pemeliharaan. Hal ini menunjukkan kondisi hiperosmotik, di mana secara fisiologis badan ikan diharuskan dapat mengatasi pengaruh perbedaan tekanan osmosis antara plasma, ruang- ruang intra seluler dan lingkungannya. Cekaman hiperosmotik mengakibatkan air masuk secara osmosis ke dalam badan ikan (Villee et al., 2002). Pada kondisi hiperosmotik ikan akan mengekspresikan kelebihan air melalui mekanisme yang menyebabkan urinnya menjadi encer.

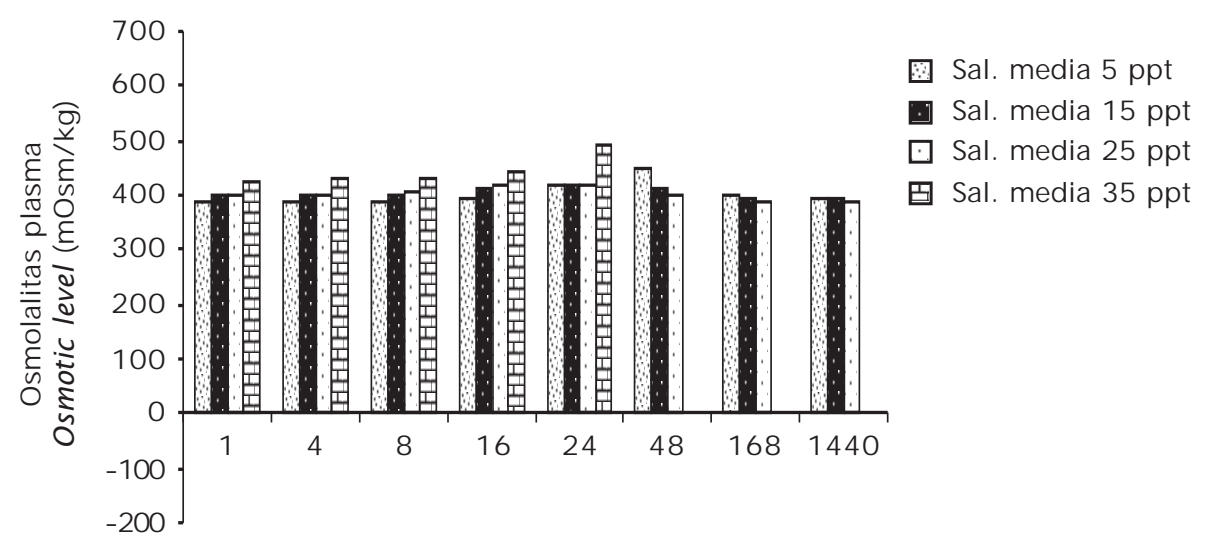

Lama pemaparan (jam)

Exposure period (hours)

Gambar 1. Osmolalitas plasma nila GIFT yang dipapar dengan tingkat salinitas dan waktu yang berbeda

Figure 1. Osmotic level of GIFT tilapia exposed to different salinity levels and different exposure periods 


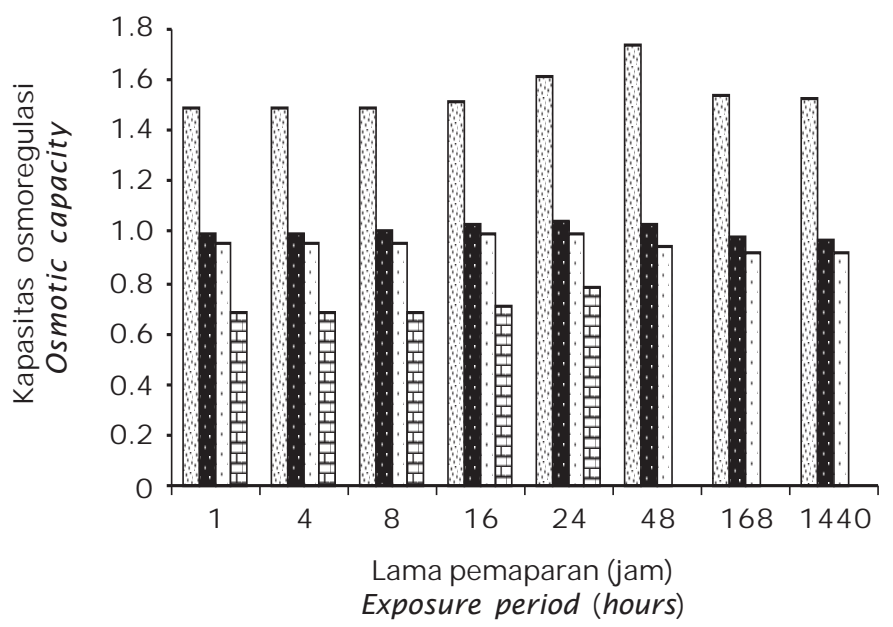

Sal. media 5 ppt

- Sal. media $15 \mathrm{ppt}$

Sal. media 25 ppt

回 Sal. media 35 ppt

Gambar 2. Kapasitas osmoregulasi nila GIFT yang dipapar dengan tingkat salinitas dan waktu yang berbeda

Figure 2. Osmotic capacity of GIFT tilapia exposed to different salinity levels and exposure periods

Kelebihan air ini disebabkan oleh adanya air lingkungan masuk ke dalam badan melalui difusi. Ikan akan mengabsorbsi garam dari medium untuk mengganti garam yang hilang ke lingkungan bersama urin.

Kondisi isoosmotik didapatkan pada pemaparan medium $15 \pm 2$ ppt dan $25 \pm 2$ ppt, di mana nilai kapasitas osmoregulasinya berada pada kisaran $1(0,99-1,04)$. Kondisi menunjukkan bahwa ikan memiliki nilai osmolalitas plasma yang relatif sama dengan nilai osmolalitas medium. Pada kondisi ini ikan dapat hidup dengan optimal, tanpa kesulitan mengekskresi ataupun mengabsorbsi garam dari medium.

Pada pemaparan salinitas $35 \pm 2$ ppt, nila GIFT menghasilkan nilai kapasitas osmoregulasi 0,68-0,78. Nilai ini menunjukkan bahwa nilai osmolalitas plasma ikan < osmolalitas medium pemeliharaan. Hal ini menunjukkan kondisi hipoosmotik, di mana secara fisiologis badan ikan diharuskan mengekskresi kelebihan garam yang masuk ke dalam badan untuk menjaga keseimbangan homeostatisnya. Cekaman hipoosmotik mengakibatkan air akan bergerak keluar dari ruang ekstra seluler ke medium (Sambasivia, 1987). Pergerakan air ini membuat cairan ekstra seluler menjadi lebih pekat daripada cairan intraseluler, yang menyebabkan keluarnya air dari sel.
Pergerakan air dari dan ke dalam badan ikan dapat terukur dari persentase kadar air badan ikan. Pada pemaparan salinitas $35 \pm 2$ ppt terjadi kematian total ikan setelah 24 jam pemaparan. Kematian diakibatkan oleh ketidakmampuan mereka mengatasi pengaruh perbedaan tekanan osmosis antara plasma, ruang- ruang intra seluler dan lingkungannya. Keluarnya air dari badan sepertinya merupakan penyebab kematian ikan nila. Karena jika berlangsung terus- menerus ikan akan mengalami dehidrasi dan mati. Ville et al. (2002) melaporkan bahwa konsentrasi garam yang semakin tinggi akan menyebabkan air yang terdapat dalam badan ikan keluar, sehingga ikan akan mengalami dehidrasi dan dapat mengalami kematian. Untuk mengatasi perbedaan salinitas, Anguilla anguilla melakukan mekanisme pengaturan fisiologisnya untuk mencegah pengaruh dehidrasi dengan menjaga komposisi cairan badan dan osmolalitas (Kalujnaia, 2007).

Hasil penelitian ini selaras dengan beberapa penelitian pada ikan nila, Oreochromis sp. sebelumnya (Haryadi, 2003); pada sidat, Anguilla bicolor McClelland (Susilo \& Sukmaningrum, 2007); dan pada kijing air tawar, Velesunio ambiguus Phillipi (Widarto \& Lucas, 1995). Namun hasil ini berbeda dengan hasil penelitian Susilo \& Rachmawati (2008), di mana regulasi osmotik ikan nila (Oreochromis sp.) optimal pada salinitas 10 ppt 


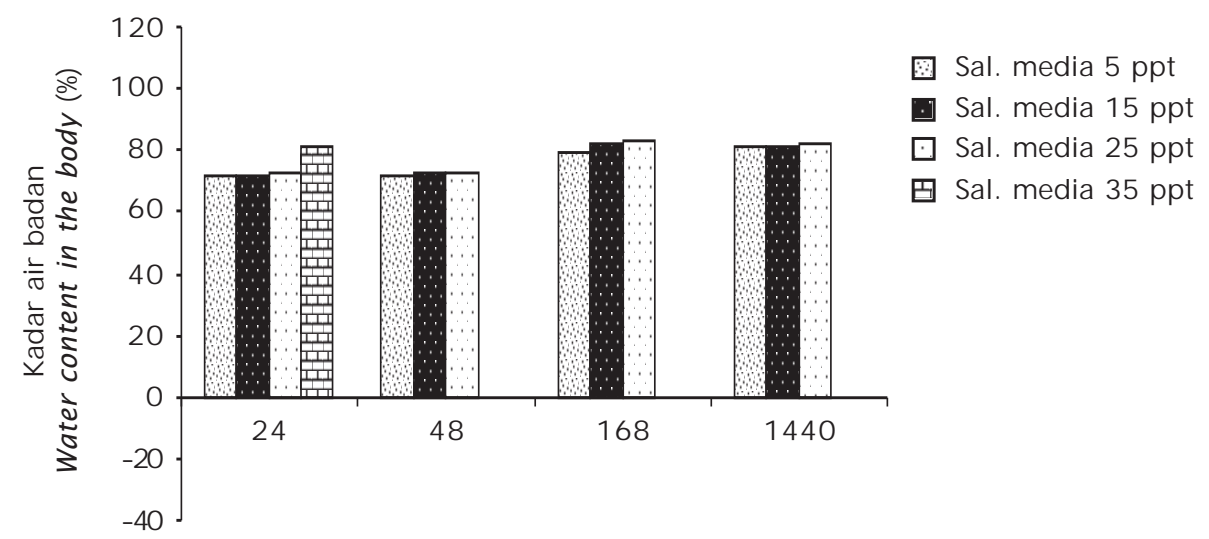

Lama pemaparan (jam)

Exposure period (hours)

Gambar 3. Persentase kadar air badan nila GIFT yang dipapar dengan tingkat salinitas dan waktu yang berbeda

Figure 3. Water content in the body mass of GIFT tilapia exposed to different salinity levels and exposure periods

dengan kapasitas osmoregulasi mendekati 1. Sedangkan pada hasil penelitian ini, tingkat osmotik nila GIFT optimal didapatkan pada kisaran salinitas $15 \pm 2$ ppt sampai salinitas $25 \pm 2$ ppt. Hal ini mengindikasikan bahwa nila GIFT lebih toleran terhadap kisaran nilai salinitas air yang tinggi dibandingkan dengan nila varietas lokal lainnya.

Kadar air badan ikan yang dipapar dengan tingkat salinitas dan waktu pemaparan yang berbeda tertera pada Gambar 3. Persentase kadar air badan mencerminkan pergerakan air dari dan ke dalam badan ikan nila sebelum dan sesudah pemaparan cekaman salinitas.

Berdasarkan analisis ragam, perbedaan salinitas dan lamanya waktu pemaparan tidak berpengaruh nyata $(P<0,05)$ terhadap persentase kadar air badan nila GIFT. Kadar air badan nila GIFT yang dipapar pada medium bersalinitas $5 \pm 2,15 \pm 2$ dan $25 \pm 2$ ppt pada lama pemaparan 24-1440 jam berkisar $71,41 \%$ $82,05 \%$ Pengukuran pada pemaparan salinitas $35 \pm 2$ ppt hanya dilakukan sampai pemaparan 24 jam, dikarenakan semua ikan mati setelah pemaparan 24 jam.

Hasil ini menunjukkan bahwa kapasitas osmoregulasi nila GIFT dalam pengaturan air tidaklah terlalu berarti. Hingga akhir penelitian ( 2 bulan), tidak ada kadar air badan ikan yang mampu mencapai bobot awal badannya.
Sehingga dapat diasumsikan bahwa fluktuasi salinitas medium tidak berpengaruh terhadap persentase kadar air badan. Widarto \& Lucas (1995) melaporkan bahwa, spesies eurihalin memiliki kemampuan pemulihan kehilangan air yang lebih cepat daripada spesies stenohalin. Beberapa peneliti juga melaporkan hasil yang serupa, pada kijing air tawar, Velesunio ambiguus (Pierce, 1982; Widarto \& Lucas, 1995), pada sidat, Anguilla bicolor McClelland (Susilo \& Sukmaningrum, 2007), dan pada ikan nila Oreochromis sp. (Susilo \& Rachmawati, 2008).

\section{KESIMPULAN}

Fluktuasi salinitas medium berpengaruh terhadap regulasi osmotik namun tidak berpengaruh terhadap persentase kadar air badan. Regulasi osmotik nila GIFT optimal didapatkan pada kisaran salinitas $15 \pm 2 \mathrm{ppt}$ sampai salinitas $25 \pm 2$ ppt. Pada kisaran salinitas ini, nila GIFT mampu melakukan pengaturan osmoregulasi internal menuju pemulihan (keseimbangan osmotik) mendekati tingkat osmotik lingkungan habitat aslinya setelah 24 jam cekaman salinitas. Hal ini mengindikasikan bahwa nila GIFT lebih toleran terhadap kisaran nilai salinitas air yang tinggi dibandingkan dengan nila varietas lokal lainnya. 


\section{DAFTAR ACUAN}

Anggoro, S. 1992. Efek osmotik berbagai tingkat salinitas media terhadap daya tetas telur dan vitalitas larva udang windu, Penaeus monodon F. Disertasi. Pascasarjana IPB. Bogor, $230 \mathrm{hlm}$.

Basiao, Z.U., Eguia, R.V., \& Doyle, R.W. 2005. Growth Response of Nile Tilapia Fry to Salinity Stress in the Presence of an 'Internal Reference' Fish. Aquaculture Reseach, 36: 712- 720.

Bastiawan, D. \& Wahid, A. 2011. Teknik Pembenihan Nila GIFT Secara Massal dan Pembesaran di Tambak. http:// bbatsukabumi.tripod.com/t_benih_GIFT.htm. Diakses tanggal 2 September $2 \overline{0} 11$.

Chowdhury, M.A.K., Yi, Y., Lin, C.K., \&El- Haroun, E.R. 2006. Effect of Salinity on Carrying Capacity of Adult Nile Tilapia Oreochromis niloticus L. In Recirculating Systems. Aquaculture Research, 37: 1627- 1635.

Evans, D.H. 1998. The Physiology of Fishes (second edition). CRC Press. New York, 519 pp.

FAO. 2004. Tilapias as Alien Aquatics in Asia and the Pacific: A Review. FAO Fisheries Technical Papers- T453, 74 pp.

Fineman- Kalio, A.S. 2008. Preliminary Observations on the Effect of Salinity on the Reproduction and Growth of Freshwater Nile Tilapia, Oreochromis niloticus (L.), Cultured in Brackishwater Ponds. Aquaculture Research, 19: 313- 320.

Haryadi, B. 2003. Darah dan Tekanan Osmotik Internal Ikan Nila, Oreochromis sp. yang Didedahkan dalam Medium dengan Salinitas Berbeda. Sains Akuatik, 6(1): 2733.

Hayuningtyas, E.P., Robisalmi, A., Nunuk, L., \& Didik, A. 2009. Toleransi Salinitas Benih Persilangan 3 Strain Nila (Oreochromis niloticus) dengan Ikan Mujair (O. mossambicus). J. Ris. Akuakultur, 4(3): 313318.

Kalujnaia, S., I.S. McWilliam, V.A. Zaguinaiko, A.L. feilen, J. Nicholson, N. Hazon, C.P. Cutler, R.J. Balment, A.R. Cossins, M. Hughes, \& G. Cramb. 2007. Salinity Adaptation and Gene Profiling Analysis in the European Eel (Anguilla anguilla) using Microarray Technology. General and Comparative Endocrinology, 152: 274- 280.
Kamal, A.H.M.M. \& Mair, G.C. 2005. Salinity Tolerance in Superior Genotypes of Tilapia, Oreochromis niloticus, Oreochromis mosammbicus and Their Hybrids. Aquaculture, 247: 189- 201.

Lignot, J.H., Pierot, C.S. , \& Charmantier, G. 2000. Osmoregulatory Capacity as a Tool in Monitoring the Physiological Condition and the Effect of Stress in Crustaceans. Aquaculture, 191: 209- 245.

Nolan, D.T., Op't Veld, R.L.J.M., Balm, P.H.M., \& Bonga, S.E.W. 1999. Ambient Salinity Modulates the Response of the Tilapia, Oreochromis mossambicus (Peters), to Net Confinement. Aquaculture, 177: 297- 309.

Pierce, S.K.Jr. 1982. Invertebrate Cell Volume Control Mechanism: A Coordinated Use of Intracellular Amino Acids and Inorganic Ions as osmotic Solute. Biol. Bull., 163: 405419.

Sambasivia. 1987. Ictyology. John Wiley and Sons. New York.

Susilo, U. \& Sukmaningrum, S. 2007. Osmoregulasi Ikan Sidat Anguilla bicolor McClelland pada Media dengan Salinitas Berbeda. Sains Akuatik, 10(2): 111- 119.

Susilo, U. \& Rachmawati, F.N. 2008. Regulasi Osmotik Internal Ikan Nila Oreochromis sp. pada Medium dengan Salinitas Berbeda. Sains Akuatik, 11(2): 195- 200.

Tahe, S. 2008. Pengaruh starvasi ransum pakan terhadap pertumbuhan, sintasan, dan produksi udang vaname (Litopenaeus vannamei) dalam wadah terkontrol. J. Ris. Akuakultur, 3(3): 401- 412.

Villegas, C.T. 1990. Evaluation of the Salinity Tolerance of Oreochromis mossambicus, $O$. niloticus and Their F1 Hybrids. Aquaculture, 85: 281- 292.

Villee, C.A., Walker W.F., \& Barnes, R.D. 2002. Alih bahasa Nawangsari Sugiri. Zoologi Umum ed.6, cet.3. Erlangga. Jakarta, 484 hlm.

Watanabe, W.O., Kuo, C.M., \&Huang, M.C. 1985. Salinity Tolerance of Nile Tilapia Fry (Oreochromis niloticus), Spawned and Hatched at Various Salinities. Aquaculture, 48: 159- 176.

Widarto, T.H. \& Lucas, J.S. 1995. Osmoregulasi Kijing Air Tawar (Velesunio ambiguus Phillipi). Hayati, 2(1): 34- 41. 